\title{
The Influences of Prodqual, Product Packaging, and Price in the Sales \\ Improvement(A case study at SME's in Jagakarsa sub-district, South Jakarta)
}

\author{
Mudjiarto \\ \{mudjiarto@esaunggul.ac.id\}, EconomicLecturerin UniversitasEsa Unggul, West Jakarta, Indonesia
}

\section{Nurfitri}

\{nurfitri634@gmail.com\}, StudentinUniversitasEsa Unggul, West Jakarta, Indonesia

\section{Otto R. Payangan}

\{ottopayangan1958@gmail.com\}, Faculty of Economics and Business,Hasanuddin University, Makassar, Indonesia.

\section{Musran Munizu}

\{m3.feunhas@gmail.com\}, Faculty of Economics and Business,Hasanuddin University, Makassar, Indonesia.

\author{
Jusni \\ \{jusni_mju@yahoo.co.id\}, Faculty of Economics and Business,Hasanuddin University, Makassar, Indonesia.
}

\begin{abstract}
This study aims to determine the effect of product quality (prodqual), packaging and prices as independent variables on the sales performance of SMEs as a dependent variable in Jagakarsa sub-district, South Jakarta (then called SME's). This research is a quantitative study with positivism paradigm approach survey method. The population of this study is the customer of SMEs. Data collection in this study used a questionnaire containing 26 items that were distributed to 80 respondents by applied a purposive sampling technique with analytical methods such as multiple linear regression analysis tests. The results of this study indicate that there was a significant influence of those independence variables on dependence variable, then have a positive and significant effect as well.
\end{abstract}

Keywords:

Product Quality, Packaging, Price and Sales Performance.

Article Received: 18 October 2020, Revised: 3 November 2020, Accepted: 24 December 2020

\section{Introduction}

To achieve success in today's competition, companies must role customer-oriented and retain them by providing greater value by giving the best service to consumers (Bernand ,2009 in Silaningsih. 2018). and Tjiptono, 205).It's related with Kotler and Keller (2008) that expressed satisfaction is feeling happy or disappointed someone emerged after comparing between perception on the performance or the results of a product and hope. But before those all, the first thing that company must do is to understand customer needs and desires such assess a product with its packing and make up a purchasing decision accordingly (Ryono, et al,
2016) and these efforts colud be achieved by running a good marketing communication, where as through marketing communication, companies may inform, persuade, and remind consumers, both directly and indirectly, of their products (Kotler \& Keller, 2009). Recently, packaging has become an important marketing tool, which is need

carefully designed that could be able to create a value for consumers and a promotional value (Resmi, N, at all, 2015) ) such packaging design is also required to be as unique and attractive as possible, as it is the final advertisement seen by the consumer before they decide which brand to purchase. Furthermore, In o day competitive 
market, packaging design becomes a brand's promotional vehicle, highlighting its position on the shelf (Klimchuck\&Krasovec, 2007) in Astariet all (2011)

Kotler \& Keller (2000) categorize consumer goods based on the consumers' spending habits. The categories consist of: shopping goods, where the consumer usually compares various products based on their price or quality. Then, Tjiptono (2007) stressed that naturally, neither a good package with a bad product nor a quality product with a bad package can increase sales volume, well-designed package should provide consumer purchases. However, when same products are compared, packing plays a distinctive role by creating difference among other products. Sales function of packing also brings up the sales price issue. Consumers are willing to pay higher prices for a package designed differently and creating difference. In this case, a firm can determine a higher sales price by bearing higher packing costs and products position would be better through its packing work (Heryanto I , 2015) . Maintaining all existing customers will generally be more profitable than customer turnover, as the cost to attract new customers can be five times the cost of maintaining existing customers (Kotler et al, 2010).

The SMEs business product strives to provide what customer asked and needed, tries to develop all of its products in various attractive packaging forms, its quality products and affordable prices to satisfy and to attract consumers as well. So that consumers would have many alternative to choose product before taking the sales refinement of a product offered by SME's. Packaging with an attractive logo, color and the appropriate size gives an influence on increasing sales, then affects the increase in sales received as (Philip Kotler, 1987, and Hermawan Kartajaya,1997) in (Cenadi CS, 2000). Meaning, the more attractive packaging the more increasing sales. The other hand, price has a positive value to increase sales so that the more affordable prices offered to consumers, the more sales will increase (Hasan, Ali, 2014). If the company improperly sets the price, this will have a fatal effect on sales so then, prices offered by SMEs are quite affordable for consumers in Jagakarsa sub-district (Singh,2016) .

\section{Research Methodology}

\subsection{Resarch Methods}

The main purpose of this study that applied descriptive research methods is to describe the characteristics and details of the population such as who, what, when, where and how (Yin, 2013). Therefore, in order to carry out the study to ascertain customer satisfaction and its correlations to the variables identified in the conceptual framework, quantitative primary data collection is proposed to be collected using survey questionnaires addressed to the SMEs customers.

The population in this study are all people who have shopped at SMEs, with 400 business member population. Uses a non-probability sampling method (non-random sampling) by using purposive sampling technique. The criteria determined in sampling is the respondent age of 18 years old above, such they have been able to make decisions and made purchases in the SMEs. The number of samples obtained from this formula totaled 80 people who later became respondents to fill out the questionnaire.

\subsection{Statistic Analysis}

The study applied some test, namely validity, reliability, multiple linear regression analysis, such as (a) Validity Test, is a test used to measure the validity or validity of a questionnaire. A questionnaire is said to be valid if the question or statement on the questionnaire is able to reveal something that will be measured by the questionnaire that is an indicator or dimension of each variable as (Ghozali, 2016), (b) Reliability Test is used to measure a questionnaire which is an indicator of the variable as (Ghozali, 2016) and (c) Multiple Linear Regression Analysis, is a phenomenon that influences the condition of the dependent variable (Y), because almost all conditions that affect a factor are caused by more 
than one independent variable $(\mathrm{X})$ as (Efferin et.al, 2008).

\section{Result and Discussion}

\subsection{Validity test}

Validity test is done to find out the extent of statement in the questionnaire used (valid) to obtain data needed in the study, statement is said to be valid if in the Correlation table the

Pearson correlation value of 80 respondents obtained results with a value of $>0.361$ and said to be invalid if the value $<0.361$ can be seen from the table of critical values for product product $r$ correlation.

\subsection{Reliability Test}

Based on the results of the reliability test stated quite reliable if the Cronbach Alpha 0.41 - 0.60. If the Cronbach Alpha value is $0.61-0.80$ then the instrument or questionnaire is declared reliable, and if the Cronbach Alpha value is 0.80 then the instrument is very reliable.

\subsection{Multiple Linear Regression Analysis.}

From the results of the multiple linear, showed that regression equation $t$ is a negative constant value which means that the quality of the product, packaging is increased at an appropriate price, then sales value will increase. On the other hand shows that the value of the variable coefficient is positive, meaning that if the quality of products, packaging, and prices is getting better in convincing consumers, then sales in the smallmedium businesses will increase.

Table 1. Result Coefficient for Variable X1, X2 and X3

\begin{tabular}{|c|c|c|c|c|c|}
\hline \multirow[t]{2}{*}{ Model } & \multicolumn{2}{|c|}{$\begin{array}{l}\text { Unstandardized } \\
\text { Coefficients }\end{array}$} & \multirow{2}{*}{$\begin{array}{c}\text { Standardized } \\
\text { Coefficients }\end{array}$} & \multirow[t]{2}{*}{$\mathbf{T}$} & \multirow[t]{2}{*}{ Sig } \\
\hline & B & StdError & & & \\
\hline (Constant) & $\begin{array}{r}- \\
1,580^{-}\end{array}$ & 1,550 & & $\begin{array}{r}- \\
1,019\end{array}$ & ,311 \\
\hline $\begin{array}{l}\text { Product } \\
\text { quality }\end{array}$ & ,181 &, 050 & ,354 & 3,647 & ,000 \\
\hline $\begin{array}{l}\text { The } \\
\text { packaging }\end{array}$ & ,130 & ,038 & ,309 & 3,398 & ,001 \\
\hline Price & , 157 & 049 & ,310 & 3,201 &, 002 \\
\hline
\end{tabular}

From the table 1 above, product quality (X1), packaging (X2) and price (X3) variables have

t value with a significant level of $0,000<0.05$, so Ho is rejected and Ha is accepted.

F test

Tabel 2. Sum of Square Model

\begin{tabular}{lrrrrr} 
Model & $\begin{array}{c}\text { Sum of } \\
\text { Squares }\end{array}$ & DF & $\begin{array}{c}\text { Mean } \\
\text { Square }\end{array}$ & F & Sig. \\
\hline Regression & 79,110 & 3 & 26,370 & 17,221 &, $000^{\mathrm{b}}$ \\
Residual & 116,378 & 76 & 1,531 & & \\
$\quad$ Total & 195,488 & 79 & & & \\
\hline
\end{tabular}

The results of the calculation in Table 2, shows that based on the $\mathrm{F}$ test, independent variables namely Product Quality, Packaging and Price are simultaneously significantly influence the dependent variable namely Increase in sales 
because the probability value of $\mathrm{HO}$ is rejected and Ha is accepted.

\section{Conclusion}

After doing the processing and analysis thoroughly the results can be concluded as follows:

4.1 Product quality has an effect on increasing sales of SMEs product. This means product quality has a positive value to increase SME's sales such SME's products have same quality with other products in the shop, which are of very good quality.

4.2. Packaging has an effect on increasing sales of products of SMEs.This means that the packaging with an attractive logo, color looks bright and the appropriate size gives an effect on increasing sales. The third hypothesis test which states that packaging affects increases in sales received, means that more better packaging results the more sales increase.

4.3. Prices affect the sales increase of SMEs products. This shows that the price offered is affordable for consumers has a positive value to the sales increase..

4.4. Based on research shows that product quality, packaging, and prices affect the increase in sales of SMEs products. In this study, shows that the variables of product quality, packaging and price simultaneously or jointly affect the increase SMEs sales, and the effect is positively.

4.5. Based on research shows that product quality has the most dominant variable compared to packaging and price such the product quality variable with the highest $\beta$ (beta) coefficient value among the other variables.

\section{Recommendation}

The recommendation put forward as a complement to the results of research that can be given as follows:
5.1. SME's should be able to build continuous improvement their Product Quality, Product, Packaging, and Price not only for company need means the Improvement of Sales revenue but also to pay customer needs and wants, as well.

5.2. Recommendations for future research can be addressed to the limitations of this research, namely to develop an integrated study that could be conducted as the expectation and customer requirements of customers can change over time. As the sample size of 80 is relatively poor and weak, so then further research could be done to replicate this tudy with other SME.s customer to further validate its findings.

The recommendation put forward as a complement to the results of research that can be given as follows:

5.1. SME's should be able to build continuous improvement their Product Quality, Product Packaging, and Price not only for company needs means the Improvement of Sales revenue but also to pay customer needs and wants, as well.

5.2. Recommendations for future research can be addressed to the limitations of this research, namely to develop integrated study that could be conducted as the expectation and customer requirements of customers can change over time. As the sample size of 80 is relatively poor and weak, so then further research could be done to replicate thisstudy with other SME.s customer to further validate its findings.

\section{References}

[1] Cenadi, C. S.: Peranan Desain Kemasan Dalam Dunia Pemasaran. Nirmana, 2(2), 92-103 (2000)

[2] Hasan, Ali.:Marketing and .Selected .Cases. Book I, Second Printing. Publisher: CAPS, Yogyakarta (2014)

[3] Heryanto, I.:Analysis of the Effect of Products, Prices, Distribution and Promotion of Purchasing Decisions and 
their Implications on Customer Satisfaction. Economics, Business and Entrepreneurship, 9(2), 80-101(2015)

[4] Keller dan Kotler.:Marketing Management. Vol. I. Jakarta 13th Edition: Erlangga (2009)

[5] Keller, Kotler.:Fundamentals of Marketing Management Book I, First Print. Publisher: CAPS, Yogjakarta (2008)

[6] Kotler, Philip.: Marketing Management, Millennium Edition, Jilid 2nd, PT Prenhallindo, Jakarta (2002)

[7] Kotler.:Marketing Management. Mileinium Edition. Jakarta: PT. Indeks Kelompok Gramedia (2000)

[8] Kotler.: Marketing Management. Volume Two Twelfth Edition.Jakarta: Erlangga (2007)

[9] Kotler.:Marketing Management. Thirteenth Edition of the Third Volume. Publisher: Intermedia. Jakarta (2008)

[10] Resmi, N., and Wismiarsi, T.: Effect of Packaging and Price on Purchasing Decisions of Isotonic Drinks. Management and Business, 13(2007), 1-20 (2015)

[11] Riyono and Budiharja, G. E.: Effect of Product Quality, Price, Promotion and Brand Image on Purchasing Decisions of Aqua Products in Pati City. STIE Semarang, ISSN : 2252-826, 8(2), 92-121 (2016)

[12] Singh, R. (2016) Advertising Effectiveness Of Mobile Phone Users: A Study Of College Students In Aizawl Of Mizoram. Volume 5, Number 2ISSN (Print): 23199032, (Online): 2319-9040

[13] Tjiptono, Fandy.: Marketing Strategy, Third Edition. Andi Publisher, Yogyakarta (2018)

[14] Yin, R. K.: Case study research: Design and methods. Sage publications (2013) 